\title{
A Phytosociological Study on the Community of Palaquium gutta (Hook.f.) Baill. (Sapotaceae) at Ayer Hitam Forest Reserve, Selangor, Malaysia
}

(Suatu Kajian Fitososiologi ke atas Komuni Palaquium gutta (Hook.f.) Baill di Simpan Ayer Hitam, Selangor)

\author{
A.R. SARAH*,H. NURADNILAILA, N.W.HARON \& M. AZANI
}

\begin{abstract}
A phytosociological study on the flora and vegetation community of Palaquium gutta (Hook.f.) Baill. was carried out in Compartment 13 of Ayer Hitam Forest Reserve, Selangor. The main objectives of this study were to identify, characterize and classify the P. gutta community which is naturally distributed in Ayer Hitam Forest Reserve. A total of 10 plots $(30 \times 30$ $m$ in size) were constructed according to the line transect method. The vegetation sampling and data analysis were done according to the Braun-Blanquet approach. The results showed that there were 59 species belonging to 54 genera and 34 families in the form of herbs, shrubs, understorey trees and also canopy tree layers. The most common species in the study area were P. gutta and Endospermum diadenum (Miq.) Airy Shaw. The phytosociological study identified a community of Palaquium gutta-Endospermum. diadenum along with two sub-communities known as Dracaena sp. sub-community and Streblus elongatus sub-community. The results also showed that most of the species belong to the Euphorbiaceae. This indicates that the forest is a secondary forest.
\end{abstract}

Keywords: Braun-Blanquet; Endospermum diadenum; Palaquium gutta; phytosociology; vegetation community

\section{ABSTRAK}

Suatu kajian fitososiologi ke atas flora dan komuniti vegetasi Palaquium gutta (Hook.f.) Baill, telah dijalankan di petak 13 Hutan Simpan Ayer Hitam, Selangor. Objektif utama kajian ini ialah untuk mengenal pasti, menciri dan mengelaskan komuniti P. gutta yang tersebar secara semula jadi di Hutan Simpan Ayer Hitam. Sejumlah 10 plot (30×30 m) telah dibina mengikut kaedah transek garisan. Pensampelan vegetasi dan analisis data telah dilakukan mengikut pendekatan BraunBlanquet. Keputusan menunjukkan terdapat 59 spesies dan 54 genus serta 34 famili herba, pokok renek, pokok lapisan bawah dan juga lapisan pokok kanopi. Spesies paling kerap dijumpai di kawasan kajian ialah P. gutta dan Endospermum diadenum (Miq.) Airy Shaw. Kajian fitososiologi telah mengenal pasti satu komuniti iaitu Palaquium gutta-Endospermum diadenum ass. nova diikuti dengan dua subkomuniti dikenali sebagai subkomuniti Dracaena sp. dan subkomuniti Streblus elongatus. Keputusan juga menunjukkan bahawa kebanyakan spesies adalah daripada Euphorbiaceae. Ini menunjukkan bahawa hutan tersebut adalah hutan sekunder.

Kata kunci: Braun-Blanquet; Endospermum diadenum; fitososiologi; komuniti vegetasi; Palaquium gutta

\section{INTRODUCTION}

Phytosociology involves plant communities within the same environment, their floristic composition and development and the social relationships between them. A phytosociological study gives information on the distribution of species as well as affinities between species or groups of species, resulting in a valuable evaluation of the vegetation within the study area (FrenedozoSoave 2003). A phytosociological system is a system for classifying these communities. Phytosociology provides useful basic data for ecology, geography, landscape science, conservation and environmental science because the data represent integrated units in vegetation systems (Fujiwara 1987).

According to Enright and Nuñez (2013), BraunBlanquet pioneered the classification of vegetation into units (associations) based on floristic composition and the identification of characteristics species. The advantages and problems, associated with the phytosociological approach to vegetation analysis pioneered by Braun-Blanquet have been reviewed many times, and inevitably will continue to do so as the vegetation science community increasingly becomes a globalised one.

Palaquium gutta is known locally as 'Nyatoh Taban Merah' and is from the Sapotaceae family. Palaquium species can be found in primary lowland forest about 300 $\mathrm{m}$ below and also on hill forest in Peninsular Malaysia. Palaquium species have been recorded in all states of Malaysia except Perlis, Kedah and north of Terengganu (Roche \& Dourojeanni 1984). According to Prakash et al. (2005), Palaquium species are natural inhabitants of Southeast Asia, particularly in Malaysian and Indonesian archipelago. Gutta-percha is a dried coagulated extract from several Palaquium species including $P$. gutta. The gutta-percha yielding tree is a medium to tall trees, in which a series of cuts (concentric or v-shaped cuts) is 
made to obtain the latex. The inertness of gutta-percha to biodegradation makes them useful as an impermeable coating for undersea cables and gutta-percha is still used in dentistry as a filling material (van Beilen \& Poirier 2012). Ayer Hitam Forest Reserve is a lowland dipterocarp forest which contains valuable wood, medicinal and economic plants and is also suitable for recreation. It had been selectively logged from 1936 to 1965 (Faridah-Hanum 1999). The main silvicultural operations in the 1950's were associated with timber extraction. Anthropogenic disturbances such as logging operations, construction of new roads, land development, shifting cultivation and uncontrolled deforestation are believed to be the major causes in the decline of biodiversity. Logging operations in the tropical forest impairs the ecological balance and devaluates the original forest. Lack of care during partial felling operations resulted in the damage to residual stand and young trees. Logging could also affect the watershed areas. Some 3.15 million ha of the total natural forest in hilly areas are protected as water catchment areas (Zakri 1995).

The main objectives of this study were to identify, characterize and classify the $P$. gutta community which is naturally distributed in Ayer Hitam Forest Reserve. An excellent way to conserve this valuable tropical tree species would be to know its composition and the ecological relationship between the species within its community and this could be achieved with a phytosociological study. Furthermore, the knowledge gained from this phytosociological study will contribute to the mass planting of P. gutta and this indirectly could help in the past or future logging issues in Ayer Hitam Forest Reserve. Knowledge on the floristic composition (phytosociology) of P. gutta at natural forest in Malaysia is literally unknown and an empirical botanical documentation provides a main stimulus for the present study.

\section{MATERIALS AND METHODS}

\section{STUDY SITE}

This study was conducted at Compartment 13 of Ayer Hitam Forest Reserve. Its latitudes is between $2^{\circ} 57^{\prime} \mathrm{N}$ and $3^{\circ} 04^{\prime} \mathrm{N}$ and longitudes between $101^{\circ} 38^{\prime} \mathrm{E}$ and $101^{\circ} 41^{\prime} \mathrm{E}$. The forest is a lowland dipterocarp forest and is known as a secondary disturbed forest due to the previous logging activities since 1930. Currently, the total forest area is 1248 ha.

The mean annual temperature is $25.2^{\circ} \mathrm{C}$ with a maximum temperature at $27.6^{\circ} \mathrm{C}$ and minimum at $22.9^{\circ} \mathrm{C}$. The rainy season occurs in January-March and JuneSeptember and the average annual rainfall is $2178 \mathrm{~mm}$. The topography of the forest is rather undulating with 15 and $233 \mathrm{~m}$ above sea level. The soil type in Ayer Hitam Forest Reserve is alluvium-colluvium soil which reshaped from metamorphic rock with sandy clay loam soil texture. There are three major rivers in the study area which are Sungai Rasau, Sungai Bohol and Sungai Biring.

\section{FIELD SURVEYS AND DATA COLLECTION}

Field surveys and data collection were done based on the techniques described in detail by Braun-Blanquet (1964) and Fujiwara (1987). A total of 10 plots with $30 \times 30 \mathrm{~m}$ in size were constructed according to the line transect method. The size of the plot was estimated by means of a 'minimal area' which was $900 \mathrm{~m}^{2}$ for each plot. The plots were located at various altitudes, expositions, inclinations and reliefs. An effort was made to achieve high ecological and physiognomic homogeneity within each the plot. Every plot was georeferenced with a Garmin GPS.

Scientific names of each vascular plant species in each plot were identified. Cover or abundance data of all vascular plant species for each plot were verified. All vascular plant species in each plot with a trunk diameter at breast height $(\mathrm{DBH}) \geq 5 \mathrm{~cm}$ were marked and numbered and their diameter and height were recorded. Trunk perimeter measurement was taken using a metric tape and tree height was estimated with the aid of a clinometer. Lastly, these samples were classified in a phytosociological table according to their floristic composition. The vegetation layers in the forest were divided into five layers as shown in Table 1 .

\section{DATA ANALYSIS}

As for the numerical analysis, the cover or abundance values on the scale of Braun-Blanquet were transformed into the 1-9 ordinal scales of van der Maarel (1979). With the goal of identifying the floristic composition of these groups, this synthetic phytosociological table was elaborated by scoring species in percentage or constancy classes according to Braun-Blanquet's scale. Lastly, the associations of the species were described based on all the 10 plots.

\section{RESULTS}

\section{COMMUNITY STRUCTURE AND FLORISTIC COMPOSITION}

A total of 59 species belonging to 54 genera and 34 families were identified in all the 10 plots. The most dominant life forms were trees, followed by herbs and shrubs. A new community Palaquium gutta-Endospermum diadenum and two sub-communities known as Dracaena sp. subcommunity and Streblus elongatus sub-community were determined in this study and these associations were shown in the association table (Table 2).

TABLE 1. Types of vegetation layers

\begin{tabular}{lcc}
\hline Vegetation layers & Height & Symbol \\
\hline Super tree & $\geq 30 \mathrm{~m}$ & $\mathrm{ST}$ \\
Canopy tree layer & $10-25 \mathrm{~m}$ & $\mathrm{~T} 1$ \\
Understory tree layer & $6-9 \mathrm{~m}$ & $\mathrm{~T} 2$ \\
Shrub layer & $2-5 \mathrm{~m}$ & $\mathrm{~S}$ \\
Herb layer & $0.1-2 \mathrm{~m}$ & $\mathrm{H}$ \\
\hline
\end{tabular}


TABLE 2. Association table

\begin{tabular}{|c|c|c|c|c|c|c|c|c|c|c|}
\hline Plot reference number & 1 & 2 & 3 & 4 & 5 & 6 & 7 & 8 & 9 & 10 \\
\hline Original plot number in field & 1 & 5 & 4 & 6 & 2 & 3 & 9 & 10 & 8 & 7 \\
\hline Number of species & 35 & 31 & 31 & 34 & 22 & 24 & 27 & 18 & 21 & 24 \\
\hline \multicolumn{11}{|c|}{$\begin{array}{l}\text { Character and differential species } \\
\text { of Palaquium gutta-Endospermum diadenum community }\end{array}$} \\
\hline Palaquium gutta & 4 & $\mathrm{r}$ & 3 & 3 & 2 & 2 & 3 & + & 2 & + \\
\hline Endospermum diadenum & 2 & $\mathrm{r}$ & + & $\mathrm{r}$ & 2 & 2 & 2 & + & + & + \\
\hline Agrostistachys longifolia & 4 & 3 & 4 & 4 & . & 2 & 4 & 2 & 4 & + \\
\hline Gonystylus sp. & 3 & 2 & 1 & + & 2 & 2 & + & $\mathrm{r}$ & + & + \\
\hline Blumeodendron calophyllum & 1 & + & + & . & 1 & $\mathrm{r}$ & + & + & + & $\mathrm{r}$ \\
\hline Calamus sp. & 4 & 1 & 4 & 3 & 3 & . & 2 & $\mathrm{r}$ & 3 & 4 \\
\hline Diospyros argentea & 3 & $\mathrm{r}$ & + & $\mathrm{r}$ & 3 & + & $\mathrm{r}$ & . & $\mathrm{r}$ & $\mathrm{r}$ \\
\hline Knema sp. & 2 & 1 & 2 & $\mathrm{r}$ & 2 & 1 & $\mathrm{r}$ & . & + & . \\
\hline Phyllanthus pulcher & 3 & 3 & . & + & 3 & 3 & 2 & 1 & 3 & 2 \\
\hline Rothmannia macrophylla & 4 & + & 3 & 2 & . & 2 & + & + & $\mathrm{r}$ & + \\
\hline Canarium sp. & 3 & $\mathrm{r}$ & + & $\mathrm{r}$ & . & . & + & + & + & + \\
\hline Calophyllum sp. & 2 & $\mathrm{r}$ & $\mathrm{r}$ & + & 2 & $\mathrm{r}$ & . & $\mathrm{r}$ & $\mathrm{r}$ & . \\
\hline Dipterocarpus crinitus & $\mathrm{r}$ & + & $\mathrm{r}$ & $\mathrm{r}$ & + & 1 & $\mathrm{r}$ & . & . & . \\
\hline Elateriospermum tapos & 2 & 2 & 2 & $\mathrm{r}$ & 1 & . & $\mathrm{r}$ & . & + & + \\
\hline Eugeissona tristis & 4 & . & 1 & 3 & 4 & . & + & 4 & 4 & + \\
\hline Knema hookeriana & 2 & $\mathrm{r}$ & . & $\mathrm{r}$ & 2 & + & + & $\mathrm{r}$ & $\mathrm{r}$ & $\mathrm{r}$ \\
\hline Pavetta sp. & 4 & + & + & + & 2 & 1 & $\mathrm{r}$ & . & . & + \\
\hline Pellacalyx saccardianus & 3 & $\mathrm{r}$ & 1 & + & . & . & 2 & 1 & 3 & + \\
\hline Scaphium macropodum & 2 & 1 & + & + & . & . & + & $\mathrm{r}$ & $\mathrm{r}$ & $\mathrm{r}$ \\
\hline Shorea macroptera & + & . & . & $\mathrm{r}$ & + & + & + & $\mathrm{r}$ & $\mathrm{r}$ & $\mathrm{r}$ \\
\hline Syzygium sp. & 2 & $\mathrm{r}$ & 2 & + & 2 & 1 & $\mathrm{r}$ & . & . & + \\
\hline
\end{tabular}

Differential species of Dracaena sp. sub-community

Dracaena $\mathrm{sp}$.

Polyalthia sp.

Artocarpus sp.

Anisophyllea griffithii

Lijndenia laurina

Ochanostachys amentacea

Barringtonia racemosa

Oncosperma horridum

Selaginella intermedia

Cyathea latebrosa

Pternandra echinata

Semecarpus curtisii

Melastoma malabathricum

Chassalia chartacea

\begin{tabular}{|cccc|}
\hline 3 &. & 2 & 1 \\
3 & $\mathrm{r}$ & $\mathrm{r}$ & $\cdot$ \\
2 &. & + & $\cdot$ \\
3 & + &. & $\mathrm{r}$ \\
2 &. & + & $\mathrm{r}$ \\
3 & 2 &. & $\cdot$ \\
2 &. & 2 &. \\
. & + &. & + \\
4 & 4 &. & 3 \\
. & 3 &. &. \\
. &. & 3 & + \\
$\mathrm{r}$ & $\mathrm{r}$ &. & $\mathrm{r}$ \\
. &. & + & 1 \\
1 &. &. & + \\
\hline
\end{tabular}

Differential species of Streblus elongatus sub-community

Streblus elongatus

Durio zibethinus

Lasianthus oblongus

Macaranga triloba

Pandanus sp.

Vitex vestita

Macaranga gigantea

Companion species

Shorea parvifolia

Acrotrema costatum

Artocarpus elasticus

Dillenia indica

Shorea laevis

Bouea oppositifolia

Bauhinia integrifolia

Aglaia sp.

Garcinia nervosa

Hopea beccariana

Trema cannabina

Gironniera nervosa

Lithocarpus wallichianus

Mischocarpus pentapetalus

Palaquium maingayi

Campnosperma auriculatum

Porterandia anisophylla

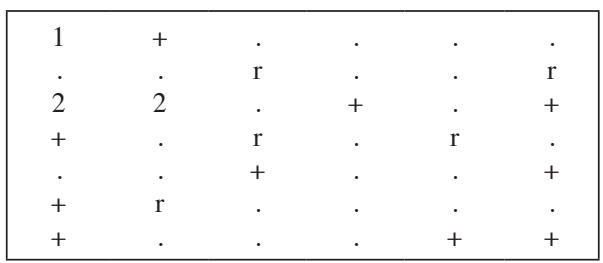


A total of 21 species belonging to 21 genera and 13 families were found in the Palaquium guttaEndospermum diadenum community. This community was characterized by $P$. gutta and E. diadenum as the dominant tree species. Other characteristics and differential species of the community were Agrostistachys longifolia, Gonystylus sp., Blumeodendron calophyllum, Calamus sp., Diospyros argentea, Knema sp., Phyllanthus pulcher, Rothmannia macrophylla, Canarium sp., Calophyllum sp., Dipterocarpus crinitus, Elateriospermum tapos, Eugeissona tristis, Knema hookeriana, Pavetta sp., Pellacalyx saccardianus, Scaphium macropodum, Shorea macroptera and Syzygium sp. This community consisted of all four forms of layers which were herbs, shrubs, understory trees and canopy tree layers. The highest layer was $25 \mathrm{~m}$ while the lowest layer was below $2 \mathrm{~m}$ with the thickness of litter layer at $5.2 \mathrm{~cm}$ in average.

A total of 14 species belonging to 13 genera and 10 families were found in Dracaena sp. sub-community. The characteristic and differential species of this sub-community were Dracaena sp., Polyalthia sp., Artocarpus sp., Anisophyllea griffithii, Lijndenia laurina, Ochanostachys amentacea, Barringtonia racemosa, Oncosperma horridum, Selaginella intermedia, Cyathea latebrosa, Pternandra echinata, Semecarpus curtisii, Melastoma malabathricum and Chassalia chartacea. Meanwhile, the Streblus elongatus sub-community consisted of seven species belonging to seven genera and seven families. The characteristics and differential species of this sub-community were Streblus elongatus, Durio zibethinus, Lasianthus oblongus, Macaranga triloba, Pandanus sp., Vitex vestita and Macaranga gigantea.

\section{SPECIES RICHNESS COVERAGE}

Plot 2 had the highest coverage of herbs layer which was $65 \%$ of total coverage and followed by plot 5 with $50 \%$ of total coverage (Figure 1). Plots 1, 3, 9 and 10 had $45 \%$ total coverage of herb layer and this was followed closely by plots $4,6,7$ and 8 with $40 \%$ total coverage of herb layer. For shrub layer, plot 6 had the highest percent of total coverage $35 \%$ and followed closely by plot 8 with $30 \%$ total coverage of shrub layer. Plots 5, 9 and 10 had a $25 \%$ total coverage of shrub layer. Meanwhile, plots 1,4 and 7 had $20 \%$ total coverage of shrub layer, leaving plot 2 with $15 \%$ total coverage and plot 3 with $10 \%$ total coverage of shrub layer.

For the T2 layer, both plots 3 and 7 had the highest percentage of total coverage $30 \%$ and followed by plots 1 and 4 with $25 \%$ total coverage. Plots 8,9 and 10 had $20 \%$ of T2 layer coverage and plots 2, 5 and 6 had $15 \%$ total coverage of $\mathrm{T} 2$ layer.

For T1 layer, plot 10 had the highest percentage of total coverage $20 \%$, followed by plots 3 and 4 with $15 \%$ total coverage of T1 layer. Plots 1, 5, 6, 8 and 9 had $10 \%$ of total coverage and plots 2 and 7 had the lowest total coverage of $\mathrm{T} 1$ layer $(5 \%)$.

All the plots showed that herb layer had the highest percentage of coverage followed closely by shrub layer. Meanwhile, both T1 and T2 layers had the lowest percentage of total coverage compared to shrub and herb layers.

The trees in the study area could not regain its original height due to the slow regeneration caused by previous logging and other anthropogenic disturbances. Thus, this has resulted to the absent of ST (trees with height above 30

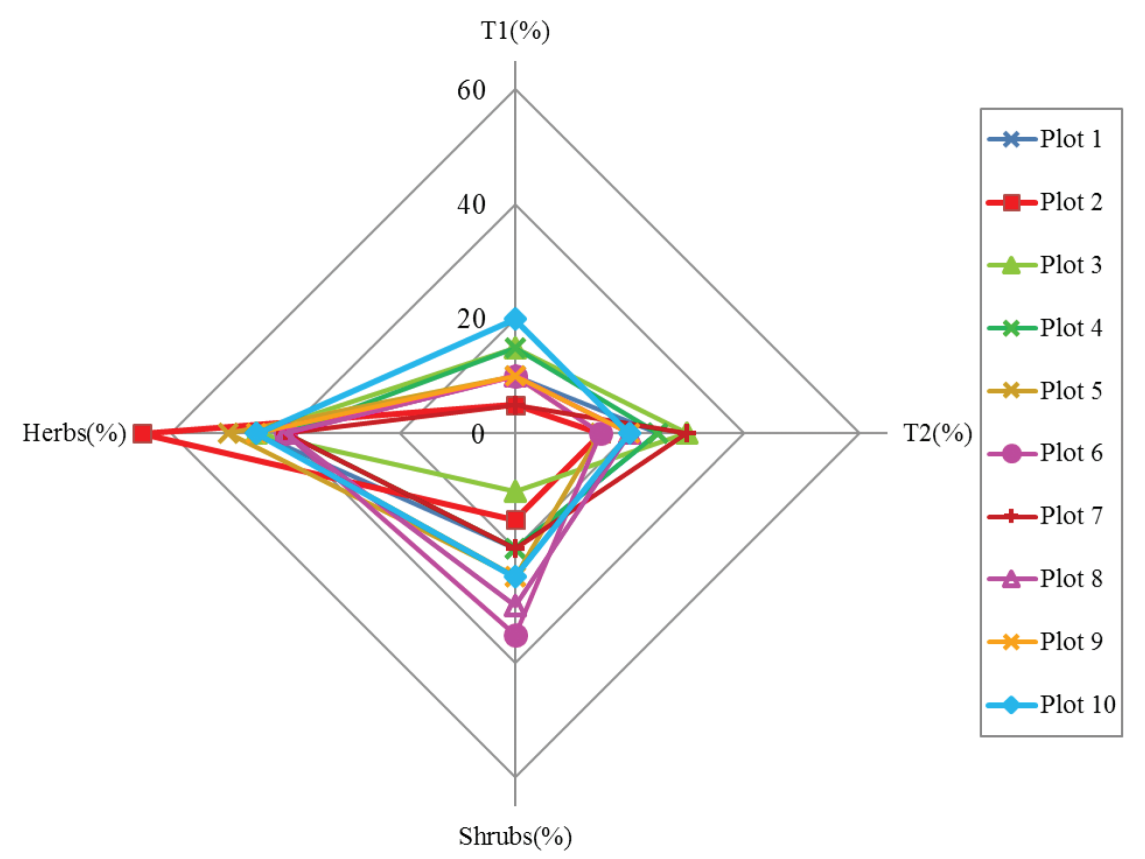

FIGURE 1. Species-richness polygon of all the 10 plots in Compartment 13, Ayer Hitam Forest Reserve 
m) and the low coverage of T1 and T2 layers in the study area.

\section{DISCUSSION}

The present study has recorded a total of 59 species belonging to 54 genera and 34 families from all the 10 plots at Ayer Hitam Forest Reserve. Meanwhile, previous study by Faridah-Hanum and Khamis (2004) recorded a total of 430 species of seed plants belonging to 203 genera and 72 families from all parts of Ayer Hitam Forest Reserve. Understanding the species composition and diversity can enlighten our knowledge of newer species as well as their behaviour in a particular forest type (Mardan et al. 2013). The environmental gradient in particular the soil gradient plays an important role in influencing the distribution of vegetation communities of a particular forest ecosystem (Nurfazliza et al. 2012).

This study has shown that $P$. gutta, E. diadenum, A. longifolia and several other species can be found in all the four vegetation layers and in a several plots. Most of these species grew in colonies or were in certain population. Thus, it is feasible that trees of some species could grow as a group and spread across several plots (Kwan \& Whitmore 1970). The lesser known wood species (LKS) such as Mahang (Macaranga sp.), Sesenduk (E. diadenum) and Terap (Artocarpus sp.) emerged in large quantity in secondary forest and could become as potential alternative supply of raw material for wood based industries (Ang et al. 2014).

Previous logging affected the nutrient in soil and contributed to the slow regeneration of the trees. Thus, the trees could not regain its original height which has resulted to the absence of emergent strata (trees with height above $30 \mathrm{~m}$ ) and the low coverage of T1 and T2 layers in the study area. The slow regeneration of the trees in Ayer Hitam Forest Reserve suggests that the area was actually recovering from the past disturbance (Roland 2000). Disturbance would reduce the potential height of trees from 25 to $50 \%$ ( $\mathrm{Ng} 1983$ ).

Furthermore, anthropogenic disturbances such as visitor frequentation and adjacent land use create the habitat for exotic species. Anthropogenic disturbances, including coverage (rubbishes and tiles), trampling (paths, visitors coming from different adjacent lands and the distance to edge) and deforestation (anthropogenic caves and stumps) and indirect anthropogenic disturbances (terrain such as slope and aspect) might have integrated effect on composition and plant diversity of forest (Wang et al. 2012). High anthropogenic disturbances might increase similar non-native herb species in urban area and low disturbances might promote co-existence of wood species in suburban area (Li et al. 2012).

Trees from the family Euphorbiaceae were also common in the study area. The frequent occurrence of members of family Euphorbiaceae may indicate that the forest in the study area is disturbed (Ekarelawan 1995).
Secondary forest is usually characterized by species such as Macaranga sp., Melastoma malabathricum and zingiberaceous plants (Miyagi et al. 1988).

Despite the existence of some species commonly distributed, this study has also shown several species that have occurred only once or twice in all the plots. This factor suggests that the tropical forest consists of many aggregated species and small numbers of randomly distributed species (Hubbell 1979; Masaki et al. 1992; Tanouchi \& Yamamoto 1995; Yamamoto et al. 1995). The distribution of $73 \%$ of tree species in a 52 ha forest dynamics plot in Bornean mixed dipterocarp forest were significantly aggregated on one of the four soil types which were sandy loam, loam, fine loam and clay (Russo et al. 2005).

With the present rapid rate of clearing and logging, it is predicted that there will be fewer primary or virgin forests exist in the future, and most of what available then will be disturbed, logged-over or secondary forests (Lajuni \& Latiff 2013). Biologists are concerned that disturbed, logged-over and secondary forests are not as good as primary forests in term of species diversity, composition, biomass and structure.

\section{CONCLUSION}

Based on the high percentage of herbs, the $P$. gutta community in Ayer Hitam Forest Reserve is actually a secondary forest and is evolving into a primary forest. Restoration of $P$. gutta will become more feasible with all the basic information on the $P$. gutta community obtained in this study. The composition and distribution of species in this study were influenced by environmental factors such as natural forest gap, soil mineral viability, altitude and the topography. This study is only a preliminary research, thus, further research should be conducted on those mentioned factors especially the altitude. This study provides information on the growth response of the mixed dipterocarp forest for development of proper forest management.

\section{REFERENCES}

Ang, A.F., Zaidon, A., Bakar, E.S., Mohd Hamami, S., Anwar, U.M.K. \& Jawaid, M. 2014. Possibility of improving the properties of Mahang wood (Macaranga sp.) through phenolic Compreg technique. Sains Malaysiana 43(2): 219-225.

Braun-Blanquet, J. 1964. Pflanzensoziologie, Grundzuge der Vegetationskunde. 2nd ed. Vienne: Spring-verlag. p. 631.

Ekarelawan. 1995. Phytosociological investigation of the south facing slope of Gunung Ledang Montane Forests, Peninsular Malaysia. Master Dissertation. Universiti Putra Malaysia (unpublished).

Enright, N.J.\& Nuñez, M.A. 2013. The Braun-Blanquet reviews in plant ecology: In honour of our founding editor, Josias Braun-Blanquet. Plant Ecology 214(12): 1417-1418.

Faridah-Hanum, I. 1999. Plant diversity and conservation value of Ayer Hitam Forest, Selangor, Peninsular Malaysia.Pertanika Journal Tropical Agricultural Science 22(2): 73-83. 
Faridah-Hanum, I. \& Khamis, S. 2004. A Guide to the Common Plants of Ayer Hitam Forest, Selangor, Peninsular Malaysia. Serdang: University Putra Malaysia Press. p. 219.

Frenedozo-Soave, R.D.C. 2003. Phytosociological studies on natural establishment of vegetation in an unreclaimed limestone mining. Brazilian Archives of Biology and Technology 46(2): 259-269.

Fujiwara, K. 1987. Aims and methods of phytosociology of 'vegetation science'. Plant Ecology and Taxonomy. Kobe: The Kobe Geobotanical Society. pp. 607-628.

Hubbel, S.P. 1979. Tree dispersion, abundance and diversity in a tropical dry forest. Science 203: 1299-1309.

Kwan, W.Y. \& Whitmore, T.C. 1970. On the influence of soil properties on species distribution in a Malayan lowland dipterocarp rainforest. Malayan Forester 33: 42-54.

Lajuni, J.J. \& Latiff, A. 2013. Biomass and floristic composition of Bangi Permanent Forest Reserve, a twice-logged lowland dipterocarp forest in Peninsular Malaysia. Sains Malaysiana 42(10): 1517-1521.

Li, Z., Zhang, Z.W., Wang, Y.J., Wang, P.C., Xu, Y.R. \& Zhou, Z.X. 2012. Influence of anthropogenic disturbances on understory plant diversity of urban forests in Wuhan, Central China. Sains Malaysiana 41(12):1495-1501.

Mardan, M.N., Hakeem, K.R., Faridah-Hanum, I. \& Saari, N.S. 2013. Tree species composition and diversity in one ha forest, Ulu Muda Forest Reserve, Kedah. Sains Malaysiana 42(10):1409-1424.

Masaki, T., Suzuki, W., Niiyama, K., Ida, S., Tanaka, H. \& Nakahizuka, T. 1992. Community structure of species rich temperate forest, Ogawa Forest Reserve, Central Japan. Vegetation 98: 97-111.

Miyagi, Y., Tagawa, H., Suzuki, E., Wirawan, N. \& Oka, N.P. 1988. Phytosociological study on the vegetation of Kutai National Park, East Kalimantan, Indonesia. Memorial Kagoshima University Research Center, Occasional Papers 14: 51-62.

Ng, F.S.P. 1983. Ecological principles of tropical lowland rainforest conservation. In Tropical Rainforest: Ecology and Management, edited by Sutton, S.L. \& Whitmore, T.C. Oxford: Blackwell Scientific Publication. pp. 359-375.

Nurfazliza, K., Nizam, M.S. \& Nur Supardi, M.N. 2012. Association of liana communities with their soil properties in a lowland forest of Negeri Sembilan, Peninsular Malaysia. Sains Malaysiana 41(6): 679-690.

Prakash, R., Gopikrishna, V. \& Kandaswamy, D. 2005. Guttapercha: An untold story. Endodontology 17(2): 32-36.

Roche, L. \& Dourojeanni, M.J. 1984. In Situ conservation of forest genetic resources in Peninsular Malaysia. A Guide to in situ Conservation of Genetic Resources of Tropical Woody Species. FAO Rome.
Roland, K.J.H. 2000. An estimate of primary productivity in Air Hitam Forest Reserve. Master Dissertation. University Putra Malaysia (unpublished).

Russo, S.E., Davies, S.J., King, D.A.\& Tan, S. 2005 . Soil-related performance variation and distributions of tree species in a Bornean rain forest. Journal of Ecology 93(5): 879-889.

Tanouchi, H. \& Yamamoto, S. 1995. Structure and regeneration of canopy species in an old-growth evergreen broad-leaved forest in Aya district, southwestern Japan. Vegetation 117: 51-60.

van Beilen, J.B. \& Poirier, Y. 2012. Plants as factories for bioplastics and other novel biomaterials. In Plant Biotechnology and Agriculture: Prospects for the $21^{\text {st }}$ Century, edited by Altman, A. \& Hasegawa, P.M. Elsevier Inc. pp. 481-494.

van der Maarel, E. 1979. Transformation of cover-abundance values in phytosociology and its effects on community similarity. Vegetation 39(2): 97-114.

Wang, Y.J., Shi, X.P., Peng, Y., Zhong, Z.C. \& Tao, J.P. 2012. Effects of fine-scale pattern of dwarf bamboo on understory species diversity in Abies faxoniana forest, southwest China. Sains Malaysiana 41(6): 649-657.

Yamamoto, S., Nishimura, N. \& Matsui, K. 1995. Natural disturbance and tree species coexistence in an old-growth beech-dwarf bamboo forest, southwestern Japan. Vegetation 117: 51-60

Zakri, A.H. 1995. Introduction: The united nation convention on biological diversity and biodiversity prospecting. In Proceedings of a Workshop on Prospects in Biodiversity Prospecting. Kuala Lumpur, 9-10 November 1994, edited by Zakri, A.H. Bangi: Genetics Society of Malaysia. pp. 13-20.

A.R. Sarah* \& N.W. Haron

Institute of Biological Sciences, Faculty of Science

University of Malaya

50603 Kuala Lumpur

Malaysia

H. Nuradnilaila \& M. Azani

Faculty of Forestry, Universiti Putra Malaysia

43400 Serdang, Selangor Darul Ehsan

Malaysia

*Corresponding author; email: sarahrazak@um.edu.my

Received: 9 July 2014

Accepted: 15 November 2014 